\title{
Hydrological response of a small catchment located in extremely humid monsoonal climate - the Maw- Ki-Syiem case study (Cherrapunji, Meghalaya Plateau, India)
}

Pedagogical University of Cracow, Institute of Geography, Podchorazych 2, 30-082 Cracow, Poland. E-mail: tbryndal@up.krakow.pl

(Received July 2, 2014: Revised accepted November 14, 2014)

The study is focused on hydrological response of a catchment to rainfall in extremely humid monsoonal climate region at the Meghalaya Plateau (India) near Cherrapunji. This area has been rarely investigated due to the lack of the detailed hydro-meteorological data. Hourly rainfall data were collected between 1999 and 2009 and hydrological data obtained for the Maw-KiSyiem experimental catchment $\left(0.22 \mathrm{~km}^{2}\right)$ was used to calibrate hydrological models (SCS-CN and GIUH) and to model river runoff during rainy periods in 2005. Hydrographs revealed rapid responses of the catchment to heavy rainfall. The rising limb and recession limb were very steep and coincided with hourly course of rainfall. A hydrological response with a maximum flow lower than $2.5 \mathrm{~m}^{3} \cdot \mathrm{s}^{-1}$ and the maximum specific flow lower than $11 \mathrm{~m}^{3} \cdot \mathrm{s}^{-1} \cdot \mathrm{km}^{-2}$ was observed for the rainfall of less than $20 \mathrm{~mm} \cdot \mathrm{h}^{-1}$. Precipitation higher than $80 \mathrm{~mm} \cdot \mathrm{h}^{-1}$, resulted in a maximum flood peak higher than $24 \mathrm{~m}^{3} \cdot \mathrm{s}^{-1}$ and a maximum specific flow exceeding $109 \mathrm{~m}^{3} \cdot \mathrm{s}^{-1} \cdot \mathrm{km}^{-2}$. The maximum specific flow in the Maw-Ki-Syiem experimental catchment is one of the highest recorded values in the world.

\section{Introduction}

Annual rainfall exceeding 10, $000 \mathrm{~mm}$ is noted at several sites over the globe (Chow ven Te et al., 1988). These rainfalls are usually associated with the monsoonal circulation over mountain ranges or isolated high massifs (Soja and Singh, 2004). In the southern part of Meghalaya Plateau (see Fig. 1A for location) the monsoonal circulation strengthened by local topography creates favorable conditions for heavy rains along the margins of the plateau (Starkel et al., 2002; Monirul Qader Mirza, 2003; Sato, 2013). The escarpment rising up to the elevation of $1200 \mathrm{~m}$ (along Dauki Fault) creates a barrier for humid air masses which flow from the Indian Ocean and predispose strong updrafts (Murata et al., 2007). As a result, the annual precipitation in the southern parts of the Meghalaya Plateau exceeds $11,000 \mathrm{~mm}$ (Cherrapunji $25^{\circ} 14^{\prime} \mathrm{N}, 91^{\circ} 44^{\prime} \mathrm{E}, 1311 \mathrm{~m}$ a.s.l. and Mawsynram stations $25^{\circ} 18^{\prime} \mathrm{N}, 91^{\circ} 35^{\prime} \mathrm{E}, 1401 \mathrm{~m}$ a.s.l.), whereas rainfall recorded in the vicinity of this region is lower than $3,300 \mathrm{~mm}$ (Starkel et al., 2002). It is notable that, the Meghalaya Hills represent only $2 \%$ of the area of the Ganges, Brahmaputra and Meghna basins, though they account for about $20-25 \%$ of the rainfall input between March and June (Hofer, 1997). The rainfall over the southern slopes of the Meghalaya Hills is thus very important in the flood processes noted in Bangladesh (Hofer and Messerli, 2006; Murata et al., 2008).

The Cherrapunji region is known as one of the rainiest places in the world. The mean annual rainfall is 11, $371 \mathrm{~mm}(1852-2000)$ and the daily rainfalls may exceed $600 \mathrm{~mm}$; with the maximum up to $1,563 \mathrm{~mm}$ recorded on $16^{\text {th }}$ June 1995 (Rakhecha and Clark, 1999; Soja and Starkel 2004; Guhathakurta 2007). Progressing deforestation, extensive cultivation and overgrazing of slopes combined with superficial exploitation of mineral resources resulted in degradation of soil cover, exposure of hard rocks and formation of an impermeable residual crust on the surface (Soja and Starkel, 2007). These conditions accelerate the water cycle. Taking into account climatic and environmental settings of this region, high values of the maximum specific flow should be expected. In the Cherrapunji, the precipitation has been monitored by the Indian Meteorological Observatory since 1852. Seasonality, long and short-term fluctuations, trends and mechanisms triggering heavy rains were mainly studied (Soja and Singh, 2004; Murata et al., 2007; Dhar and Farooqui 1973; Sato, 2013). However, there is a lack of information related to the hydrological response of the river catchments located in such extremely humid conditions. Catchments near Cherrapunji are not hydrologically controlled and there is lack of hydrologic investigations except for the study conducted in the Maw-Ki-Syiem experimental catchment by a Polish-Indian group of researchers (Starkel et al., 2002; Froehlich et al., 2003). Therefore the aims of the paper are: (1) to present and evaluate hydrological response of a catchment located in an exceptionally humid monsoonal climate to extreme rainfall, (2) to estimate the highest values of the maximum specific flow and (3) to relate them to the records for other parts of the World. 


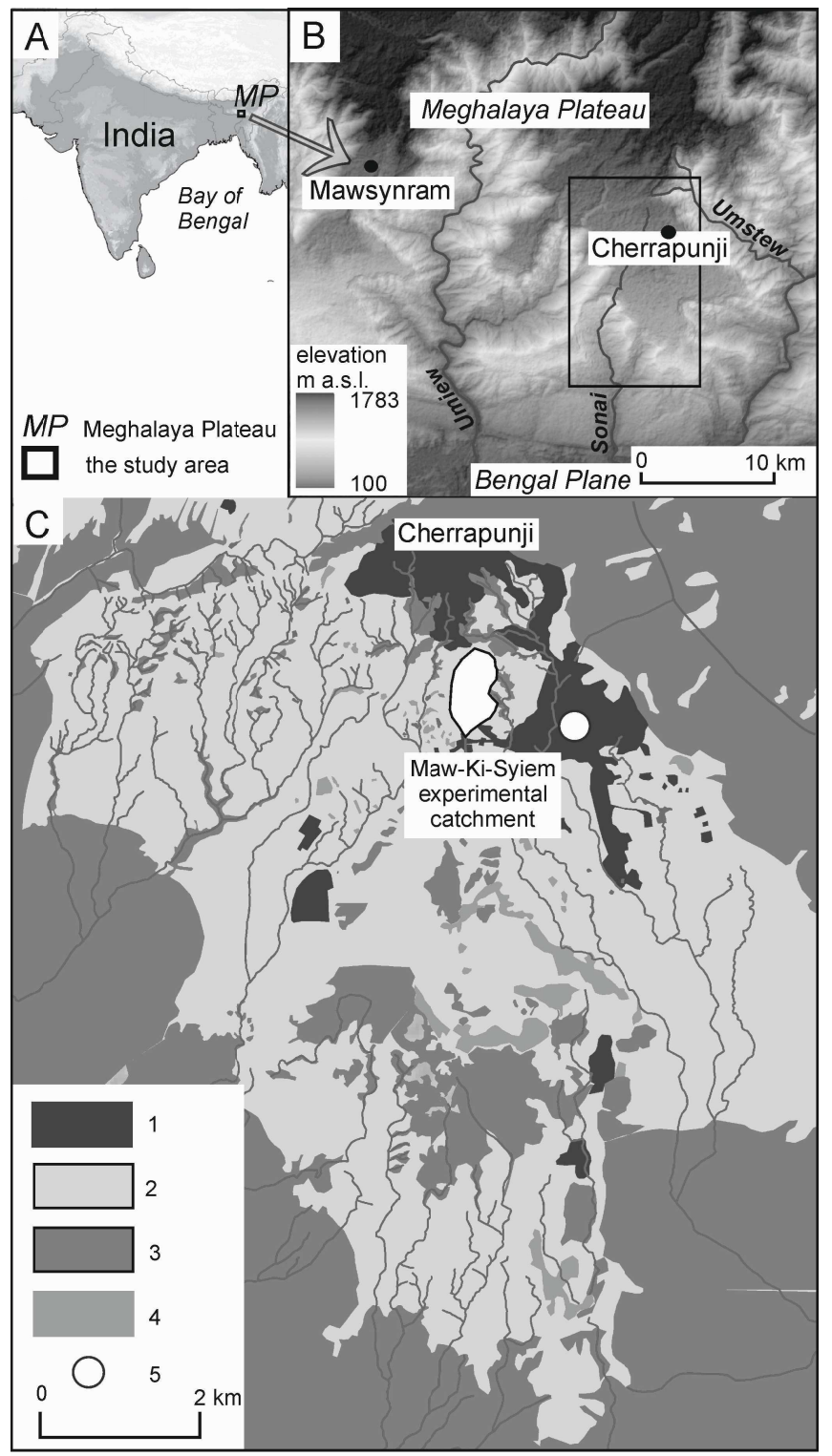

Figure 1. The study area. Location of the Meghalaya Plateau - A, Relief of the southern part of the Meghalaya Plateau near Cherrapunji-B, land cover-C. 1 - settlement areas, 2-grassland areas, 3-forest areas, 4-escarpments, 5-location of pluviometer.

\section{The study area}

The study area covers part of the Meghalaya Plateau located near Cherrapunji (Fig. 1B). This area is mainly composed of sandstones and silstones. In the southern part, thin limestone complexes occur (Prokop and Starkel, 2004). The southern part of the study area is restricted by a high escarpment incised by canyons 600-1000 m deep (Fig. 1B) and covered by sub-tropical forest (Starkel et al., 2002) Fig. 1B, C. The surface of the plateau is undulating with relief energy of up to $150 \mathrm{~m}$. Small, bare rock outcrops, of both natural and anthropogenic origin, occur occasionally (Fig. 1C). The soil cover is extremely thin $(25-50 \mathrm{~cm})$, with gravely pavement of about $2-5 \mathrm{~cm}$ (Starkel et al., 2002). The network system is composed of small creeks (1-2 km in length) of NNE-SSW direction (Fig. 1C) which drain catchments up to $9 \mathrm{~km}^{2}$ in area. They are tributaries of Umiew, Sonai and Umstew rivers (Fig. 1B). Temperature varies from $16^{\circ} \mathrm{C}$ in winter to $26^{\circ} \mathrm{C}$ in summer. Most of the rain falls during summer (MaySeptember) because of the effective S-W summer monsoon (O'Hare, 1997). The natural environment was significantly transformed by people. Nowadays, this area is mainly covered by grasslands (Fig. 1C). A forest-scrub like formation occupies steeper parts of the slopes (Froehlich et al., 2003).

In this area, the Maw-Ki-Syiem catchment was identified in 2000 as the experimental basin for the analysis of hydrological and geomorphological processes and soil erosion. The catchment is about $0.22 \mathrm{~km}^{2}$, c.a. $900 \mathrm{~m}$ long and 300-400 $\mathrm{m}$ wide (Fig. 2). The maximum elevation of the catchment slopes down from a ridge of about $1400 \mathrm{~m}$ a.s.l. in the north to the $1314 \mathrm{~m}$ a.s.l. close to the road bridge, where the mouth of the experimental catchment was established. In this part of the catchment, the bedrock is mainly composed of sandstone, interbedded with siltstones and lenses of coal beds (Starkel et al., 2002). The soil cover is significantly reduced and usually ranges from 25 to $50 \mathrm{~cm}$. The catchment is drained by one main creek with several

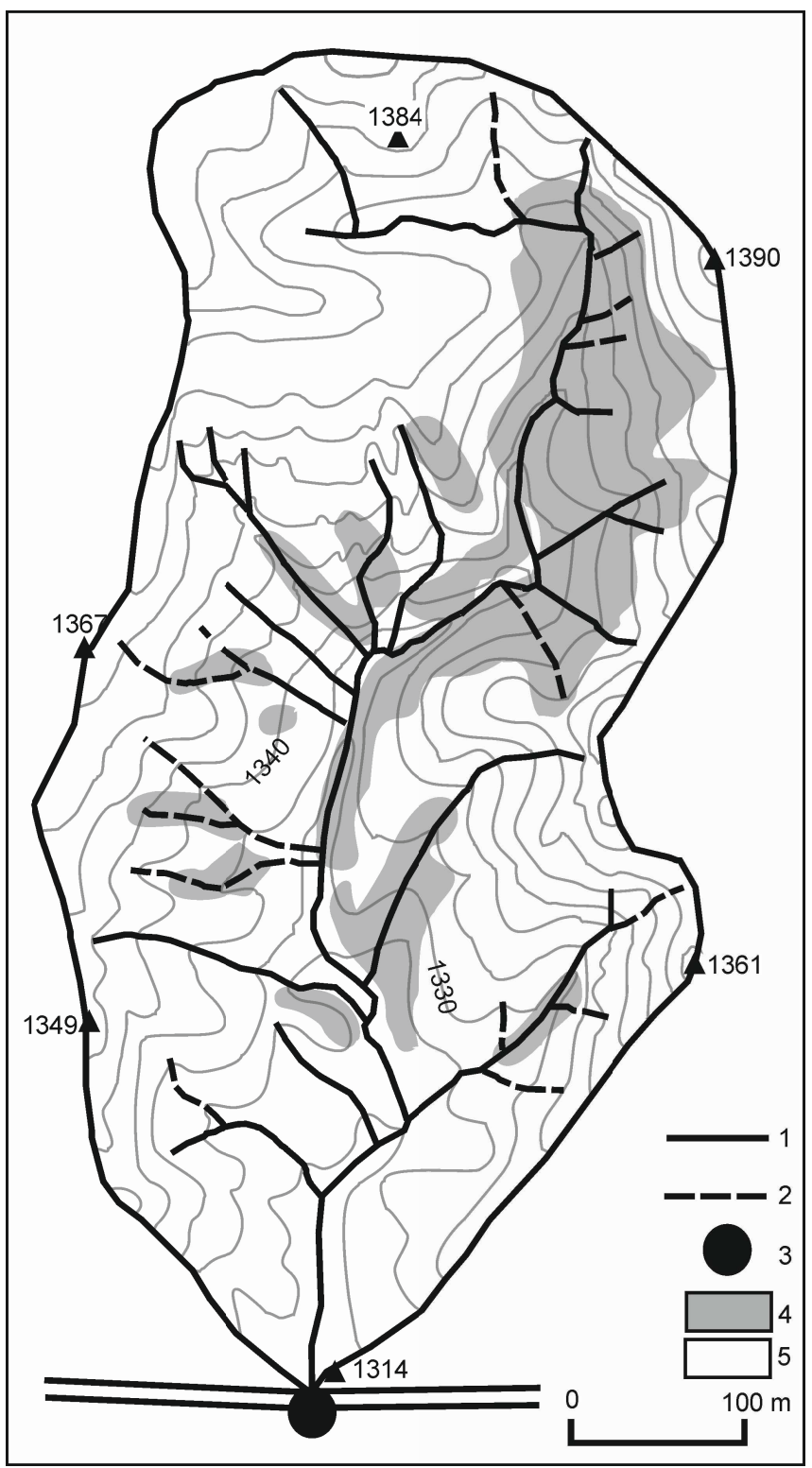

Figure 2. Maw-Ki-Syiem experimental catchment. Based on Starkel et al. 2002. 1 - permanent creeks, 2 - ephemeral creaks, 3 measurement cross-section, 4 - forest and scrub, 5 - grasslands. 
short permanent tributaries. Southward of the road the stream crosses a flat local basin and after 200-300 meters it disappears in the karstic ponor. The river network density amounts to $14 \mathrm{~km} \cdot \mathrm{km}^{2}$. The Horton (1945) and Schumm (1956) parameters calculated for this network reach: the bifurcation ratio 5.5, the length ratio 2.2 and the area ratio 1.8. Most of the slopes are deforested and grassland areas dominate (Fig. 2). The shrub-forests degraded by human activity occupy c.a. $15 \%$ of the catchment. The landforms, and soil parameters as well as the land use in the Maw-Ki-Syiem catchment are fully representative of the Cherrapunji spur (Starkel et al., 2002).

\section{Materials and methods}

Lack of continuous hydrological data for catchments near Cherrapunji hampers analysis of their hydrological responses. In order to reach the goals of this study, a hydrological modeling approach was chosen. This approach is commonly used when there are no, or there is lack of continuous, hydrological data (Jain at al., 2000; Vikrant and Sinha, 2003). Modelling of runoff in small catchments needs high-resolution rainfall data and application of models that transform rainfall into river runoff.

\section{Selection of rainfall data and identification of stormy days and rainy periods}

High-resolution rainfall data were obtained from a SEBA Hydrometric (Germany) pluviometer located near the Maw-Ki-Syiem catchment and operated from 1999 to 2006, recording rainfall with 1 -sec time resolution and at $0.1 \mathrm{~mm}$ steps. Then, the time-series of hourly rainfall were analysed in order to select the highest values. In this way, hourly time-series recorded during summer monsoon in 2005 were chosen for detailed analysis.

The hourly rainfall was transformed into daily and monthly rainfall. This allowed evaluation of the data recorded in 2005 alongside the background of the mean values for the years of 1900-2000 (Soja and Singh, 2004). A similar comparison was performed in relation to the number of rainy days (according to the definition of Indian Meteorological Department daily precipitations $\mathrm{P} \geq 2.5 \mathrm{~mm}$ ).

A daily Effective Average Rainfall criterion (DEAR) allows identification of stormy days and rainy periods (Soja and Singh, 2004). The mean value ( $\mathrm{x}$ ) and standard deviations ( $\mathrm{s}$ ) required for the DEAR were calculated on the basis of daily rainfall $\left(\mathrm{x}_{1}\right)$ for the period of March-November 2005. The " $z$ " score was calculated according to equation $\mathrm{z}=\left[\left(\mathrm{x}_{1}-\mathrm{x}\right) / \mathrm{s}\right]$. On the basis of the " $\mathrm{z}$ " score five classes of days were distinguished: 1) Wet Day z=0; 2) Stormy Day $z \geq 0.5,3$ ) Heavy Stormy Day z $\geq 1 ; 4$ ) Very Heavy Stormy Day z $\geq 1.5 ; 5$ ) Extremely Heavy Stormy Day z $\geq 2.5$. Rainy periods consist of days included in classes from 2 to 5. Evaluation of the hydrological response of the Maw-Ki-Syiem catchment was performed in relation to rainy periods.

\section{Selection and verification of models applied for hydrological modelling}

Extensive studies related to analysis of rainfall, geological settings, relief conditions, soil cover structure and its hydrological properties (e.g. retention capacity, infiltration rate), land cover and finally rainfallrunoff relationships (Starkel et al., 2002; Froehlich et al., 2003; Froehlich, 2004; Soja et al., 2004). This allowed consideration of relevant hydrological models. These studies revealed that the hydrological response of the catchment to heavy precipitation was approximately of a linear type. The hourly course of precipitation was directly reflected in the fluctuations of a water level at the catchment mouth as a result of limited retention capacity of the soil cover. Infiltration tests (the Burger's cylinder) performed during dry season in November 2000 revealed that the soil may absorb $100 \mathrm{~mm}$ of rainfall during a storm lasting 3-4 hours (Froehlich, 2004). It means that the rain intensity of above $0.4 \mathrm{~mm} \cdot \mathrm{min}^{-1}$ is absorbed by soil in 34 hours and, after that, surface flow starts (Froehlich, 2004). The saturated overland flow follows during each rain of monsoon season (Froehlich, 2004).

According to hydrological properties of the catchment that contribute to the runoff formation, the SCS-CN rainfall-runoff model (Soil Conservation Service-USDA, 1972) was adapted to simulate transformation of hourly rainfall into effective rainfall (direct runoff). The transformation of effective rainfall into a hydrograph was performed by use of the GIUH model (Rodriguez-Iturbe and Valdes, 1979). It is notable that the GIUH supported modes have been successfully applied for studies of hydrological response of catchments in the neighbouring regions (Bhaskar et al., 1997; Jain et al., 2000; Kumar et al., 2007; Bhadra et al., 2008; Nguyena et al., 2009; Narayan et al., 2012).

The models were calibrated and verified on the basis of hourly rainfall and the maximum flow obtained for several flood events recorded in the Maw-Ki-Syiem experimental catchment in June of 2002 (Froehlich et al., 2003; Soja et al., 2004). The calibration of the model referred to the highest values of the flow. Due to the small dimension of the catchment, uniform rainfall distribution was assumed. The $\mathrm{CN}$ parameter reached 91, and it was calculated in relation to the third level of Antecedent Soil Moisture Conditions (AMC III) with rainfall $53 \mathrm{~mm}$ recorded during antecedent 5-day period.

The input data required for the hydrological models were obtained from the geodatabase consisted of a raster digital elevation model $(30 \times 30 \mathrm{~m})$ and land cover and soil cover layers. The layers were created on the basis of data collected directly during research program conducted by Polish-Indian research teams (Starkel at al., 2002). Calculations of parameters required to the models were performed in Arc-GIS 9.3 software.

\section{Results and discussion}

\section{Rainfall course at Cherrapunji in 2005}

The annual patterns of rainfall in Cherrapunji are typical of a monsoonal tropical climate with a very distinct rainy summer (March - November), when active-break cycles of rainfall occur, and dry winter (December - February) when precipitation seldom occurs (Das, 1951). Three particular seasons may be distinguished (Das, 1951):

1 Pre-monsoon season - March - May (Fig. 3A) characterised by low intensity rains, however sometimes heavy downpours may reach or even exceed $300 \mathrm{~mm}$ per day. There is a significant rainfall variation ranging from $100 \mathrm{~mm}$ to $1000 \mathrm{~mm}$ during this season (Froehlich et al., 2003). In 2005 maximal daily rainfall reached $130.9 \mathrm{~mm}$, and total rainfall in this season amounted $1,492 \mathrm{~mm}$.

2 The wet summer monsoon season - June - September (Fig. 3B) when daily rainfall has significant variability. This includes rainy periods as well as significant monsoon breaks during the season (Fig. 3C). In 2005, daily rainfall reached a maximum of 329.8 


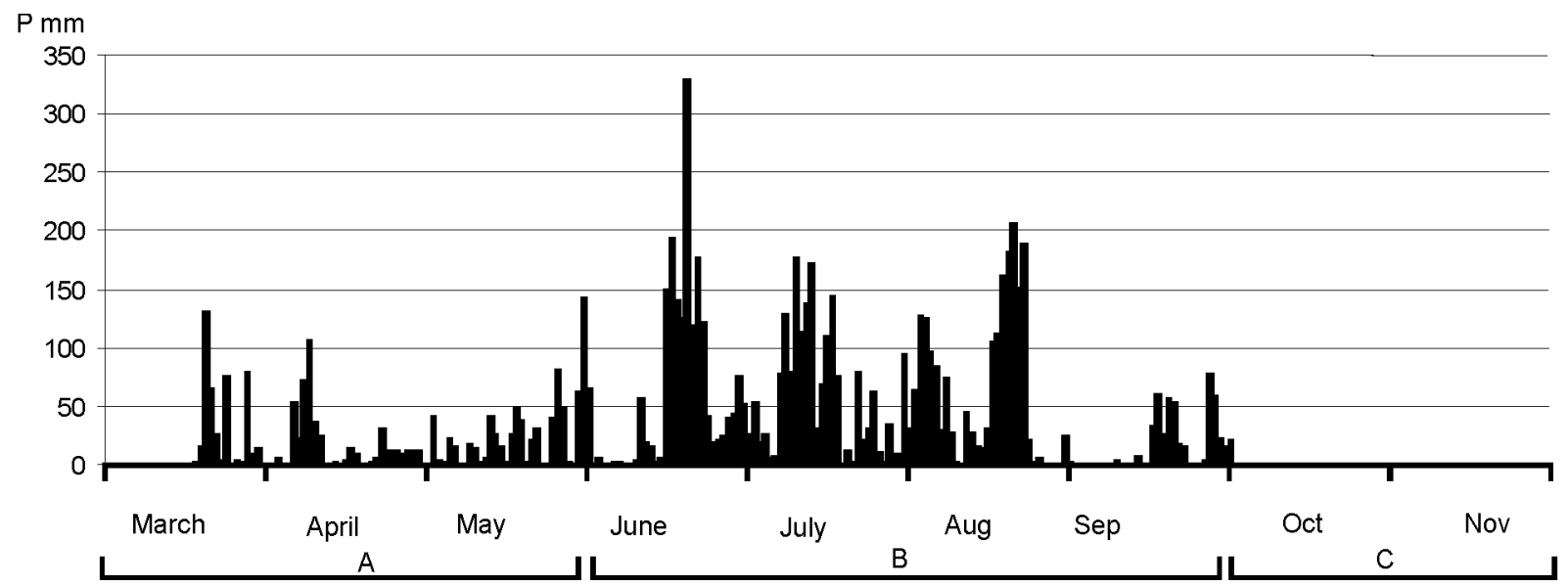

Figure 3. Daily rainfalls recorded in the Maw-Ki-Syiem catchment in Cherrapunji in 2005. pre-monsoon season-A, monsoon season-B, post-monsoon season - C

$\mathrm{mm}$ and total rainfall, in this season, reached $6095 \mathrm{~mm}$. The daily rainfall several times exceeded $170 \mathrm{~mm}$.

3 The post-monsoon season - October - November (Fig. 3C) when occasional rainstorms of shorter duration, especially in October, have been recorded. In 2005, in this season c.a. $435 \mathrm{~mm}$ rainfall was recorded.

The rainfall events in 2005 were slightly lower compare to the mean multiannual values calculated for the years 1902-2000 (Table 1). Higher rainfalls were recorded in March and August. The number of rainy days per month in 2005 was also slightly lower than mean values calculated for the years 1902-2000. Similar relationships may be noted in the average daily rainfall calculated for a rainy day.

A classification of days according to the DEAR criteria is presented in Table 2. The threshold value for Wet Day reached 55 mm. 51 Wet Days were identified from March to November. In these days $76 \%$ of total annual rainfall was recorded. The real rainfall duration amounted to $48 \%$ of rainy days (Table 3), which may be explained by the daily course of precipitation, where rain usually falls from late afternoon to early morning (Das, 1951; Starkel et al., 2002; Kataoka and Satomura, 2005; Sato, 2013). The daily rainfall

Table 1. Monthly precipitation recorded in 2005 in the Maw-Ki-Syiem catchment on the background of average values for Cherrapunji in the years $1902-$ 2000*

\begin{tabular}{|c|c|c|c|c|c|c|c|c|c|c|c|c|c|}
\hline & Jan & Feb & Mar & Apr & May & June & July & Aug & Sep & Oct & Nov & Dec & Total \\
\hline & \multicolumn{13}{|c|}{$1902-2000$} \\
\hline Mean rainfall $[\mathrm{mm}]$ & 20 & 52 & 227 & 685 & 1405 & 2608 & 2632 & 1791 & 1126 & 485 & 64 & 14 & 11109 \\
\hline Mean number of rainy days $(\mathrm{P} \geq 2.5 \mathrm{~mm})$ & 2 & 3 & 7 & 16 & 22 & 25 & 28 & 25 & 19 & 9 & 2 & 1 & 159 \\
\hline \multirow[t]{2}{*}{ Average daily rainfall in rainy day $\left[\mathrm{mm} \cdot 24 \mathrm{~h}^{-1}\right]$} & 10 & 17 & 32 & 43 & 64 & 104 & 94 & 72 & 59 & 54 & 32 & 14 & - \\
\hline & \multicolumn{12}{|c|}{2005} & \\
\hline Monthly rainfall $[\mathrm{mm}]$ & - & - & 428 & 464 & 600 & 1859 & 1836 & 2024 & 376 & 434 & 0.1 & 0.8 & 8021 \\
\hline Mean number of rainy days $(\mathrm{P} \geq 2.5 \mathrm{~mm})$ & - & - & 10 & 19 & 19 & 22 & 28 & 25 & 12 & 10 & 0 & 0 & 145 \\
\hline Average daily rainfall in rainy day $\left[\mathrm{mm} \cdot 24 \mathrm{~h}^{-1}\right]$ & - & - & 43 & 24 & 32 & 85 & 66 & 81 & 31 & 43 & 0 & 0 & - \\
\hline
\end{tabular}

Source: this study. * - after Soja and Singh, 2004.

Table 2. Classification of rainy days in 2005 according to the DEAR criteria

\begin{tabular}{|l|c|c|c|c|c|c|c|c|}
\hline & & & & \multicolumn{2}{|c|}{$\begin{array}{c}\text { Precipitation } \\
\text { (Mar-Oct 2005) } \\
7705 \mathrm{~mm}\end{array}$} & \multicolumn{3}{|c|}{$\begin{array}{c}\text { Time } \\
\text { [minutes] }\end{array}$} \\
\cline { 5 - 9 } Classes of stormy days & $\begin{array}{c}\text { The "z" } \\
\text { score }\end{array}$ & $\begin{array}{c}\text { Threshold } \\
\text { value } \\
{[\mathrm{mm}]}\end{array}$ & $\begin{array}{c}\text { No. of } \\
\text { days }\end{array}$ & $\begin{array}{c}\text { Sum } \\
{[\mathrm{mm}]}\end{array}$ & $\begin{array}{c}\text { Percentage of } \\
\text { precipitation } \\
\text { recorded in } \\
2005\end{array}$ & Days & $\begin{array}{c}\text { Real } \\
\text { rainfall } \\
\text { duration }\end{array}$ & $\begin{array}{c}\text { Percentage } \\
\text { of rainy } \\
\text { days }\end{array}$ \\
\hline Wet Day & $\mathrm{z} \geq 0$ & 55 & 51 & 5812 & 76 & 73440 & 35348 & 48 \\
Stormy Days & $\mathrm{z} \geq 0.5$ & 83 & 30 & 4268 & 56 & 43200 & 23806 & 55 \\
Heavy Stormy Days & $\mathrm{z} \geq 1$ & 111 & 24 & 3756 & 49 & 34560 & 20206 & 58 \\
Very Heavy Stormy Days & $\mathrm{z} \geq 1.5$ & 139 & 14 & 2517 & 33 & 20160 & 11767 & 58 \\
Extremely Heavy Stormy Days & $\mathrm{z} \geq 2.5$ & 195 & 2 & 536 & 7 & 2880 & 1870 & 65 \\
\hline
\end{tabular}

Source: This study. - the mean and Std.Dev of DEAR norm calculated on the daily precipitation of Mar-Oct 2005 period. 
Table 3. Identification of rainy periods in monsoon season 2005 according to the DEAR criteria.

\begin{tabular}{|c|c|c|c|c|}
\hline \multicolumn{2}{|l|}{ Date } & $\begin{array}{l}\text { June } \\
17-25\end{array}$ & $\begin{array}{c}\text { July } \\
12-16\end{array}$ & $\begin{array}{c}\text { August } \\
5-8 \\
19-26\end{array}$ \\
\hline \multicolumn{2}{|c|}{ Monthly rainfall [mm] } & 1859 & 1836 & 2024 \\
\hline \multirow[t]{2}{*}{$\begin{array}{l}\text { Rainfall in } \\
\text { rainy-period }\end{array}$} & {$[\mathrm{mm}]$} & 1357 & 599 & $\begin{array}{c}347 \\
1105 \\
\end{array}$ \\
\hline & $\%$ & 72 & 32 & $\begin{array}{l}17 \\
54\end{array}$ \\
\hline
\end{tabular}

Source: This study.

of $83 \mathrm{~mm}$ was the threshold value for Stormy Days. In the study period, 30 Stormy Days were identified. During these days $56 \%$ of total rainfall, measured in 2005, was recorded. The threshold value for Stormy Day $(83 \mathrm{~mm}$ ) was adapted for identification of rainy periods. Based on this value, four rainy periods were distinguished in 2005 (Table 3).

The rainy period in June lasted 8 days (17-24 June). In this time, $72 \%$ of monthly rainfall was recorded. During rainy periods in July (12-15) and August (5-7; 19-25) 32\% and 73\% of monthly rainfall were recorded respectively (Table 3 ). The heavy rains started frequently in the late evening and continued until early morning (Fig. 4). The highest rainfall intensity $\left(\mathrm{mm} \cdot \mathrm{min}^{-1}\right)$ was recorded during the late-night and early-morning hours. During the day time, there were 2-3 hour long breaks in rainfall with quite low intensity. Das (1951) speculated that a frontal zone of dry continental easterly or northeasterly winds and wet maritime southerly winds might explain the morning rainfall in the study area. Kataoka and Satomura (2005) simulated the late night-early morning rainfalls and suggested that the lifting effect of the Plateau or the cold pool in front of the Plateau trigger the heavy rainfall. Explanation of mechanisms of orographic precipitation around the Meghalaya Plateau has been recently presented by Sato (2013).

The highest hourly rainfall and the highest daily variability of precipitation were observed during the rainy period in June (Fig. 4). Two records were higher than $80 \mathrm{~mm} \cdot \mathrm{h}^{-1}$. The maximum rainfall reached $103.6 \mathrm{~mm} \cdot \mathrm{h}^{-1}$. This rain was recorded on $22^{\text {nd }}$ of June between 4 A.M. and 5 A.M. of the local time. The mean rainfall intensity of this storm amounted to 1.73 $\mathrm{mm} \cdot \mathrm{min}^{-1}$ and the maximum intensity reached $2.5 \mathrm{~mm} \cdot \mathrm{min}^{-1}$. The rainy periods identified in July and August represent long-lasting continuous precipitation periods with lower variability in hourly rainfalls (Fig. 4). In July, rainfall higher than $20 \mathrm{~mm} \cdot \mathrm{h}^{-1}$ was exceeded 5 times and this value was not exceeded during the rainy period in early August (5-7). During the second rainy period in August, the $25 \mathrm{~mm} \cdot \mathrm{h}^{-1}$ rainfall was exceeded 5 times and the maximum rainfall reached $53.7 \mathrm{~mm} \cdot \mathrm{h}^{-1}$ (Fig. 4). The hydrological reaction of the Maw-Ki-Syiem catchment located near Cherrapunji was analysed in relation to these rainy periods.

\section{Hydrological response of the catchment to extreme rainfall}

Hydrographs reveal a rapid response of Maw-Ki-Syiem catchment to heavy rainstorms (Fig. 5). The rising limb and recession limb of the hydrograph are very steep and coincide with the hourly course of rainfall. This fast response of the catchment (with a time of concentration lower than 1h) was emphasized by Starkel et al. (2002); Froehlich et al. (2003); Froehlich (2004) and Soja et al. (2004). It was explained by small dimensions $\left(0.22 \mathrm{~km}^{2}\right)$ and a small retention capacity that predispose overland flow formation.

The hydrograph developed for the rainy period of 17-25 June revealed two high peaks. The maximum flow of $24 \mathrm{~m}^{3} \cdot \mathrm{s}^{-1}$ was generated by hourly rainfall of $81.8 \mathrm{~mm}$, with the average intensity of this storm of $1.36 \mathrm{~mm} \cdot \mathrm{min}^{-1}$. The highest maximum flow of order $28.7 \mathrm{~m}^{3} \cdot \mathrm{s}^{-1}$ was generated by hourly rainfall of $103.6 \mathrm{~mm}$, with the mean intensity of $1.73 \mathrm{~mm} \cdot \mathrm{min}^{-1}$. Similar values of the maximum flow $\left(23-25 \mathrm{~m}^{3} \cdot \mathrm{s}^{-1}\right)$ occurred on $26^{\text {th }}$ of June 2002 . However, this flood wave was generated by a very locally-restricted rainstorm, so that the daily rainfall in Cherrapunji meteorological station

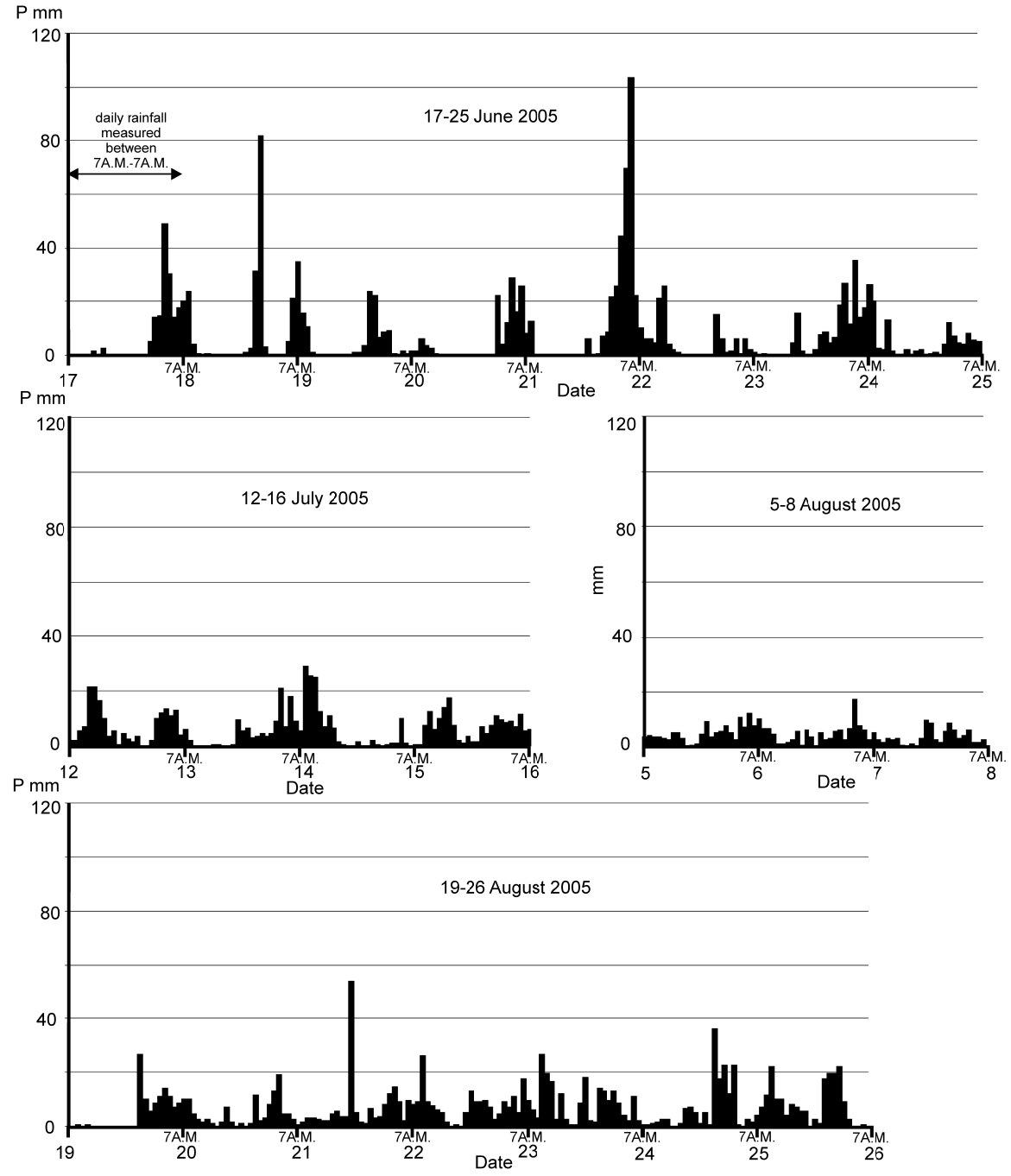

Figure 4. Hourly rainfall recorded in the main rainy periods identified in 2005 in Maw-KiSyiem catchment. 

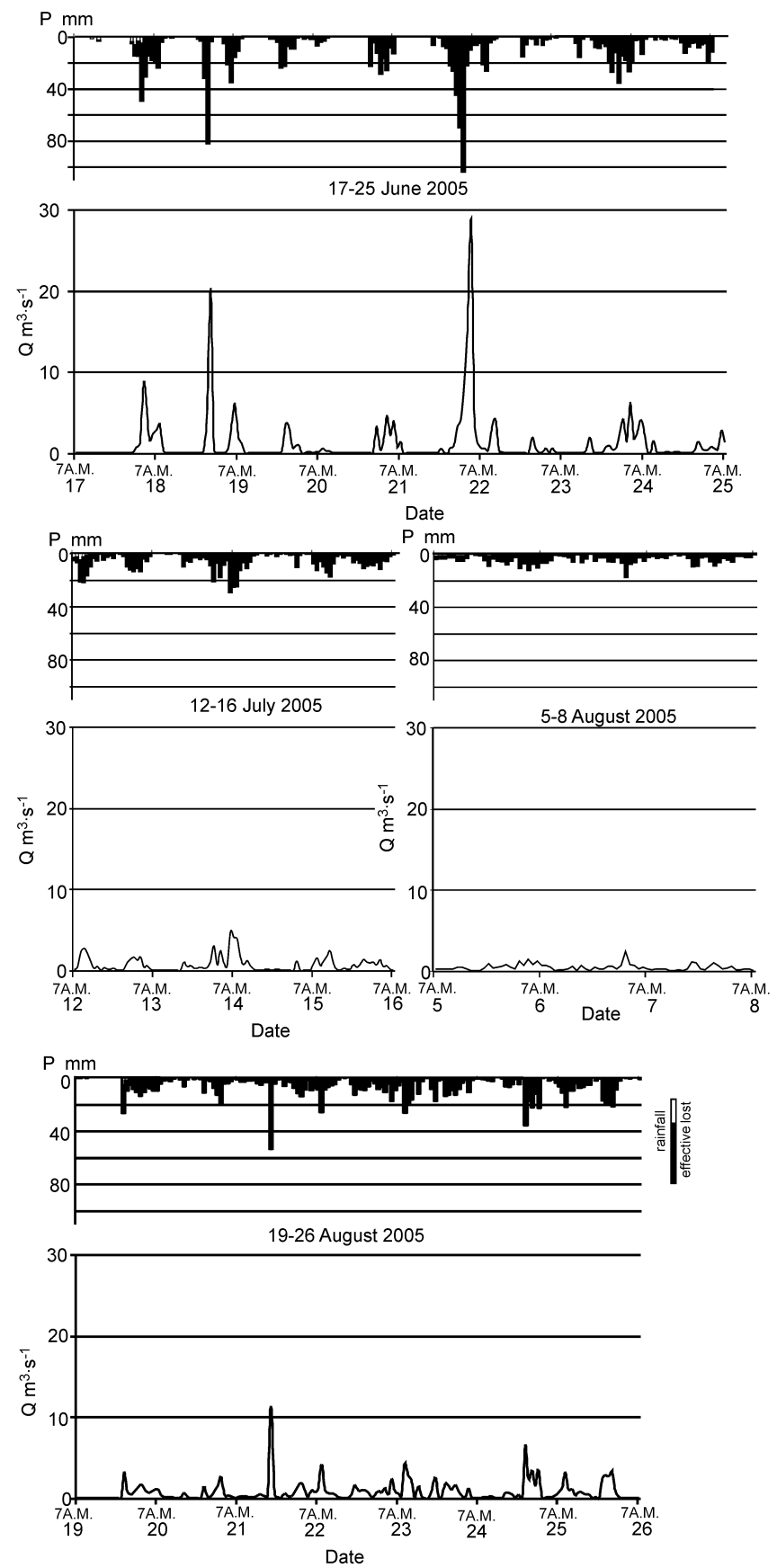

Figure 5. Hydrographs generated in Maw-Ki-Syiem catchments by hourly rainfalls, during rainy periods in 2005.

(situated $1 \mathrm{~km}$ from the catchment) reached only $50 \mathrm{~mm}$ (Soja et al., 2004).

The hydrographs developed for rainy periods during which continuous and less intensive rains occur, are characterized by significantly lower values of the maximum flow (Fig. 5). During this time, hourly rainfall, was generally lower than $20 \mathrm{~mm}$, and the mean intensity was lower than $0.33 \mathrm{~mm} \cdot \mathrm{min}^{-1}$. Such precipitation generated a maximum flow lower than $2.5 \mathrm{~m}^{3} \cdot \mathrm{s}^{-1}$ (Fig. 5). Hourly rainfall of the order of $28.92 \mathrm{~mm}\left(0.48 \mathrm{~mm} \cdot \mathrm{min}^{-1}\right)$ recorded during a rainy period on 12-16 July generated the maximum flow of $4.9 \mathrm{~m}^{3} \cdot \mathrm{s}^{-1}$. The highest hourly rainfall, recorded during the rainy period on 19-26 August reached $53.7 \mathrm{~mm}$, with the mean intensity of $0.89 \mathrm{~mm} \cdot \mathrm{min}^{-1}$. The river response of the discharge $11.4 \mathrm{~m}^{3} \cdot \mathrm{s}^{-1}$ occurred then.
Results of the modeling process are confirmed by hydrological measurements carried out in the Maw-Ki-Sayiem catchment (Froehlich et al., 2003) and detailed observations of hydrological reaction of the catchment. The field work performed in the Maw-KiSyiem catchment by R. Soja (Froehlich et al., 2003) revealed that an hourly rainfall higher than $40 \mathrm{~mm}\left(0.7 \mathrm{~mm} \cdot \mathrm{min}^{-1}\right)$ caused a rapid increase of river discharge. In particular during a storm recorded on $30^{\text {th }}$ of May 2006 a falling intensity of rainfall from $0.7 \mathrm{~mm} \cdot \mathrm{min}^{-1}$ to $0.3 \mathrm{~mm} \cdot \mathrm{min}^{-1}$ resulted in sudden drop in the water level at the mouth of catchment from $0.5 \mathrm{~m}$ to $0.1 \mathrm{~m}$. In turn, during $17-19$ of July 2004, when total rainfall of $1807 \mathrm{~mm}$ was recorded, there was no significant rise in the water. That was mainly due to the low rainfall intensity (average intensity of $0.42 \mathrm{~mm} \cdot \mathrm{min}^{-1}$ ).

\section{The maximum specific flow in Maw-Ki- Syiem catchment in the context of the World's records}

Climate conditions and environmental settings of the Cherrapunji region, suggest that the hydrological response of the catchment should be comparable with the highest values reported in the World, especially in terms of the value of the maximum specific flow.

The highest value of maximum flow for the Maw-Ki-Syiem catchment amounted to $28.7 \mathrm{~m}^{3} \cdot \mathrm{s}^{-1}$ and can be compared to the maximum flow (Qmax) obtained according to the formula Qmax $=100 \mathrm{~A}^{0.8}\left(\mathrm{~A}-\right.$ catchment area, $\left.\mathrm{km}^{2}\right)$, which was calculated by Herschy (2002) for catchments with the area larger than $12 \mathrm{~km}^{2}$ and smaller than $100 \mathrm{~km}^{2}$. The maximum flow of the Maw-Ki-Syiem $\left(0.22 \mathrm{~km}^{2}\right)$ by the Herschy's formula amounted $27.6 \mathrm{~m}^{3} \cdot \mathrm{s}^{-1}$ and it was c.a. $1 \mathrm{~m}^{3} \cdot \mathrm{s}$ ${ }^{1}$ lower than the value obtained by modelling with SCS-CN and GIUH models. This higher value of the simulated maximum flow may suggest that the value may be overestimated. In order to check this fact, a consistency test was performed. As suggested by Gaume and Borga (2008), the comparison of the specific peak discharge (in $\mathrm{mm} \cdot \mathrm{h}^{-1}$ ) and the event maximum rainfall intensity $\left(\mathrm{mm} \cdot \mathrm{h}^{-1}\right)$ should not lead to runoff rates significantly greater than 1 . In the case of Maw-Ki-Syiem, these characteristics reached respectively $103.3 \mathrm{~mm} \cdot \mathrm{h}^{-1}, 103.7 \mathrm{~mm} \cdot \mathrm{h}^{-}$ ${ }^{1}$ and 0.99 . This fact indicates that the simulated value $\left(28.7 \mathrm{~m}^{3} \cdot \mathrm{s}^{-1}\right)$ was not overestimated.

The overview of 10-top flash flood events in the World (Rodier and Roche, 1984; Costa, 1987) reveals the highest position of the Maw-Ki-Syiem catchment, where the highest values of the maximum specific flows were noted (Table 4). Most of maximum specific flows have been concerned with local flash flood events reported in catchments with the area bigger than $1.7 \mathrm{~km}^{2}$. The area of the MawKi-Syiem catchment is smaller $\left(0.2 \mathrm{~km}^{2}\right)$ and there are no data for such catchments, therefore the comparison is hampered. The differences are not large. The value calculated for the Maw-Ki-Syiem is only c.a. $18 \%$ higher than the value reported for a Humbolt river tributary near Rye Patch in Nevada (Table 4).

It is noteworthy that the maximum specific flow of the order of $30-50 \mathrm{~m}^{3} \cdot \mathrm{s}^{-1} \mathrm{~km}^{-2}$, reported in larger catchments, may occur in the Maw-Ki-Syiem catchment several times per year and it is generated by hourly rainfall higher then $40 \mathrm{~mm}$.

Flood index $K$ developed by Françou and Rodier (1969) allows to compare the magnitude of the flood regardless of the catchment area, therefore it may be considered as a good measure for the comparison. The highest values of the $K$ index calculated for extreme 
Table 4. The highest values of the maximum specific flow recorded in the World and related $\mathrm{K}$ indexes

\begin{tabular}{|c|c|c|c|c|c|c|}
\hline Name & Country & $\begin{array}{c}\mathrm{A} \\
{\left[\mathrm{km}^{2}\right]}\end{array}$ & Date & $\begin{array}{c}\text { Qmax } \\
{\left[\mathrm{m}^{3} \cdot \mathrm{s}^{-1}\right]}\end{array}$ & $\begin{array}{c}\mathrm{qmax} \\
{\left[\mathrm{m}^{3} \cdot \mathrm{s}^{-1} \mathrm{~km}^{-2}\right]}\end{array}$ & $K[-]$ \\
\hline Zita & Tunisia & 3.5 & 12.12 .1976 & 131 & 37 & 4.8 \\
\hline Soldier Creek & USA & 5.34 & 05.10 .1970 & 201 & 38 & 4.9 \\
\hline Ribeira Brava & $\begin{array}{l}\text { República de } \\
\text { Cabo Verde }\end{array}$ & 6.7 & 26.09 .1976 & 253 & 38 & 5.0 \\
\hline $\begin{array}{l}\text { Bronco creek near } \\
\text { Wikieup (Arizona) }\end{array}$ & USA & 49.2 & 18.01 .1975 & 2080 & 42.3 & 5.7 \\
\hline $\begin{array}{l}\text { Meyers canyon near } \\
\text { Mitchell (Oregon) }\end{array}$ & USA & 32.9 & 27.07.1965 & 1540 & 46.8 & 5.7 \\
\hline Riviere Blanche & Martynique & 4.3 & 20.08 .1970 & 210 & 49 & 5.0 \\
\hline Halawa Stream & USA & 12 & 02.04 .1965 & 762 & 63.5 & 5.5 \\
\hline Honopou Stream & USA & 1.7 & 18.11.1930 & 162 & 95.3 & 5.1 \\
\hline $\begin{array}{l}\text { Humbolt river tributary } \\
\text { near Rye Patch (Nevada) }\end{array}$ & USA & 2.2 & 31.05 .1973 & 251 & 114.1 & 5.3 \\
\hline Maw-Ki-Syiem & India & 0.2 & $\begin{array}{l}22.06 .2005 \\
\text { simulation }\end{array}$ & 27.8 & 139.0 & 4.8 \\
\hline
\end{tabular}

Source: this study on the basis of Rodier and Roche (1984) and Costa (1987), A - catchment area, Qmax - the maximum

flow, qmax - the maximum specific flow, $\mathrm{K}-$ the index $K$ developed by Françou and Rodier (1969).

flash flood events exceeded or were close to 5 (Table 4). In the case of the Maw-Ki-Syiem catchment the value of index $K$ was slightly lower than the values recorded in other regions of the World.

\section{Conclusion}

The Cherrapunji region has been known as a place in the World, where one of the highest rainfalls is recorded. However, this top position in the World ranking is related to long-lasting precipitations and annual records (Dhar and Farooqui, 1973; Cerveny et al., 2007). Cherrapunji holds the World's record rainfall for durations from 15 days to 2 years (Rakhecha and Singh, 2009). In terms of hydrological consequences this precipitation may generate large floods at the Bengal Plain (Monirul Qader Mirza, 2003). In this context, the Cherrapunji region has an impact on flood formation at regional level.

At the Meghalaya Plateau, near Cherrapunji, the hydrological response of catchments is determined mainly by short-duration rainstorms. This issue has been rarely investigated until now, because of a lack of hourly rainfall and continuous hydrological data. The rainfall data, collected during the Polish-Indian research programs, detailed analysis of rainfall and runoff relationships and collection of hydrological data for several flood events in the Maw-Ki-Syiem experimental catchment, allowed the researchers to use hydrological models in order to analyze hydrological response of a typical small catchment, located in extremely humid monsoonal climate conditions near Cherrapunji.

The hydrological response of the catchment is closely related to the rainfall. This may be explained by a small retention capacity within the catchment, which is reduced completely during a monsoon season. As a result of this, precipitation is transformed into effective rainfall and saturated overland flow contributes to runoff formation. The hydrographs are characterized by steep rising and recession limb, and follow the rainfall intensity.

Hourly rainfall less than $20 \mathrm{~mm}$, generates floods with the maximum flow lower than $5 \mathrm{~m}^{3} \cdot \mathrm{s}^{-1}$. Hourly rainfall higher than 40 $\mathrm{mm}$ (that correspond to average intensity of order $0.7 \mathrm{~mm} \cdot \mathrm{min}^{-1}$ ) usually causes floods with the maximum flow higher than $10 \mathrm{~m}^{3} \cdot \mathrm{s}^{-1}$. The maximum specific flow may reach at least $30-50 \mathrm{~m}^{3} \cdot \mathrm{s}^{-1} \cdot \mathrm{km}^{-2}$ several times every year. The hydrological response of the Maw-KiSyiem catchment to hourly rainfall higher than $80 \mathrm{~mm}$ (that correspond to average intensity of order $1.33 \mathrm{~mm} \cdot \mathrm{min}^{-1}$ ) has been expressed by maximum flow higher than $24 \mathrm{~m}^{3} \cdot \mathrm{s}^{-1}$. Such precipitation induces local flash flooding and, during such events, the maximum specific flow may be higher than $109^{\mathrm{m} 3} \cdot \mathrm{s}^{-1} \cdot \mathrm{km}^{-2}$.

The maximum specific flow obtained in this study $\left(139 \mathrm{~m}^{3} \cdot \mathrm{s}\right.$ $\left.{ }^{1} \cdot \mathrm{km}^{-2}\right)$ is higher than the maxima reported in the literature. However, the relationship between the specific peak discharge and the event maximum rainfall intensity, as well as calculations related to the envelope curve developed by Hershy (2002) indicate, that Qmax $28.7 \mathrm{~m}^{3} \cdot \mathrm{s}^{-1}$ and qmax $139 \mathrm{~m}^{3} \cdot \mathrm{s}^{-1} \cdot \mathrm{km}^{-2}$ calculated in this study are not overestimated. A similar conclusion may be drawn on the basis of $K$ index, which allows for comparison of flood magnitudes regardless of the catchment area.

\section{Acknowledgements}

The authors acknowledge three reviewers for their useful comments. These significantly helped in improving the quality of the manuscript. This study was conducted thanks to the cooperation between Polish and Indian geographers (Institute of Geography and Spatial Managements Polish Academy of Science, Cracow; North Eastern Hill University, Shillong) who investigated the environmental parameters of landscape in Cherrapunji region.

\section{References}

Bhadra, A., Pnigrahi, N., Singh, R., Raghuwanshi, N. S., Mal, B. C., and Tripathi, M. P., 2008, Development of geomorphological instantaneous unit hydrograph model for scantly gauged watersheds: Environmental Modelling \& Software, v. 23, pp. 1013-1025.

Bhaskar, N., Parida, B., and Nayak, A., 1997, Flood Estimation for Ungauged Catchments Using the GIUH: Journal of Water Resources Planning and Management, v. 123 , no. 4 , pp. 228-238.

Cerveny, R.S., Lawrimore, J., Edwards, R., and Landsea, Ch., 2007, Extreme Weather Records Compilation, Adjudication and Publication: Bulletin American Meteorological Society, v. 88, pp. 853-860.

Chow ven Te., Maidment, D.R., and Mays, L.W., 1988, Applied Hydrology: New York, McGraw-Hill Book Company. 
Costa, J.E., 1987, A comparison of the largest rainfall-runoff floods in the United States with those of the People's Republic of China and the World: Journal of Hydrology 96, pp. 101-115.

Das, J.C., 1951, On certain aspects of rainfall at Cherrapunji: Indian Journal Meteorology . Geophysics, v. 2, pp. 197-202.

Dhar, O.N., and Farooqui, S.M.T., 1973, A study of rainfalls recorded at the Cherrapunji observatory: Hydrological Science Bulletin, v. 18, no. 4, pp. 441-450.

Françou, J., and Rodier, J.A., 1969, Essai de classification des crues maximales: Floods and their Computation, Proceedings of the Leningrad Symposium, August 1967: Louvain, IAHS-UNESCO-WMO, pp. 518-527.

Froehlich, W., 2004, Runoff generation in experimental catchment, in: Starkel, L., and Singh, S., eds, Rainfall, runoff and soil erosion in the globally extreme humid area, Cherrapunji region Indie: Prace Geograficzne, v. 191, pp. 73-75.

Froehlich, W., Prokop, P., Singh, S., Soja, R., Starkel, L., and Syiemlieh, H., 2003, Hydrological aspects in the extremely humid area around Cherrapunji (India) - an integrated approach, in Rahmakrishnan, P.S., Saxena, K.G., Patnaik, S., and Singh, S., eds, Methodological issues in mountain research. A socio-ecological system approach: New Delhi, Oxford and IBH Publishing Co. Ptv.Ltd., pp. 219-230.

Gaume, E., and Borga, M., 2008, Post-food field investigations in upland catchments after major flash foods, proposal of a methodology and illustrations: Journal of Flood Risk Management, v. 1, pp. 175-189.

Guhathakurta, P., 2007, Highest recorded point rainfall over India: Weather, v. 62 , no. 12 , pp. $349-349$.

Herschy, R.W., 2002, The World's maximum observed ?oods: Flow Measurement and Instrumentation, v. 13, pp. 231-235.

Hofer, T., 1997, Floods in Bangladesh: A highland-lowland interaction?: Geographica Bernensia, v. G48, 178 pp.

Hofer, T., and Messerli, B., 2006, Floods in Bangladesh History, dynamics and rethinking the role of the Himalayas: Tokyo, NY, Paris, United Nations University Press.

Horton, R.E., 1945, Erosional development of streams and their drainage basins: hydrophysical approach to the quantitative morphology: Geological Society of America Bulletin, v. 56, pp. 275-370.

Jain, S. K., Singh, R. D., and Seth, S. M., 2000, Design ?ood estimation using GIS supported GIUH approach: Water Resources Management, v. 14 , pp. $369-376$.

Kataoka, A., and Satomura, T., 2005, Numerical simulation on the diurnal variation of precipitation over northeastern Bangladesh: a case study of an active period 14-21 June 1995: Scientific Online Letters on the Atmosphere, v. 1, pp. 205-208.

Kumar, R., Chatterjee, C., Singh, R. D., Lohani, A. K., and Kumar, S., 2007, Runoff estimation for an ungauged catchment using geomorphological instantaneous unit hydrograph (GIUH) model: Hydrological Processes, v. 21 , pp. $1829-1840$.

Murata, F., Hayashi, T., Matsumoto, J., and Asada, H., 2007, Rainfall on the Meghalaya plateau in northeastern India-one of the rainiest places in the World: Natural Hazards, v. 42, pp. 391-399.

Murata, F., Terao, T., Hayashi, T., Asada, H., and Matsumoto, J., 2008, Relationship between atmospheric conditions at Dhaka, Bangladesh, and rainfall at Cherrapunjee, India: Natural Hazards, v. 44, pp. 399-410.

Monirul Qader Mirza, M., 2003, Three Recent Extreme Floods in Bangladesh: A Hydro-Meteorological Analysis: Natural Hazards, v. 28, pp. 35-64

Narayan, K., Dikshit, P.K.S., and Dwivedi, S.B., 2012, GIS supported Geomorphologic Instantaneous Unit Hydrograph (GIUH) of Varuna river basin using Geomorphological characteristics: International Journal of Advances in Earth Sciences, v. 1, no. 2, pp. 68-76.

Nguyena, H.Q., Maathuisb, B. H.P., and Rientjes T. H.M., 2009, Catchment storm runoff modelling using the geomorphologic instantaneous unit hydrograph: Geocarto International, v. 25, no. 5, pp. 357-375.

O'Hare, G., 1997, The Indian Monsoon: Geography, v. 82, no. 3, pp. 218-230 and v. 82 , no. 4 , pp. $335-352$

Prokop, P., and Starkel, L., 2004, Environmental characteristics of Cherrapunji spur - relief and geology: in Starkel, L., and Singh, S., eds, Rainfall, runoff and soil erosion in the globally extreme humid area, Cherrapunji region Indie: Prace Geograficzne, v. 191, pp. 37-41.

Rakhecha, P.R., and Clark, C., 1999, Revised estimates of one-day probable maximum precipitation (PMP) for India: Meteorological. Application, v. 6 , pp. $343-350$.

Rakhecha, P.R. and Singh, V.P., 2009, Applied hydrometeorology: Dordrecht,
Springer.

Rodier, J.A., and Roche, M., 1984, World Catalogue of Maximum Observed Floods: IAHS Publications, v. 143, Wallingford, Oxfordshire.

Rodriguez-Iturbe, I., and Valdes, J.B., 1979, The geomorphologic structure of hydrologic response: Water Resources Research, v. 15, pp. 1409-1420.

Sato, T., 2013, Mechanism of orographic precipitation around the Meghalaya Plateau associated with intraseasonal oscillation and the diurnal cycle: Monthly Weather Review, v. 141, no. 7, pp. 2451-2466.

Schumm, S.A., 1956, Evolution of drainage systems and slopes in badlands and Perth Amboy, NY: Geological Society of America Bulletin, v. 67, pp. 597-646.

Soil Conservation Service-USDA, 1972, Estimation of direct runoff from storm rainfall: National Engineering Handbook Section 4-Hydrology, pp. 10.1-10.24

Soja, R., and Singh, S., 2004, The rainfall characteristic: in Starkel, L., and Singh, S., eds, Rainfall, runoff and soil erosion in the globally extreme humid area, Cherrapunji region Indie: Prace Geograficzne, v. 191, pp. 59-72.

Soja, R., Starkel, L., and Syiemlieh, J.H., 2004, Some aspects of rainfallrunoff relationship: in Starkel, L., and Singh, S., eds, Rainfall, runoff and soil erosion in the globally extreme humid area, Cherrapunji region Indie: Prace Geograficzne, v. 191, pp. 75-80.

Soja, R., Starkel, L., 2007, Extreme rainfalls in Eastern Himalaya and southern slope of Meghalaya Plateau and their geomorphologic impacts: Geomorphology, v. 84, pp. 170-180.

Starkel, L., Singh, S., Soja, R., Froehlich, W., Syiemlieh, H., and Prokop, P., 2002, Rainfalls, runoff and soil erosion in the extremely humid area near Cherrapunji, India (preliminary observations): Geographica Polonica, v. 75 , no. 1 , pp. 43-65.

Vikrant, J., and Sinha, R., 2003, Derivation of Unit Hydrograph from GIUH Analysis for a Himalayan River: Water Resources Management, v. 17, pp. $355-375$.

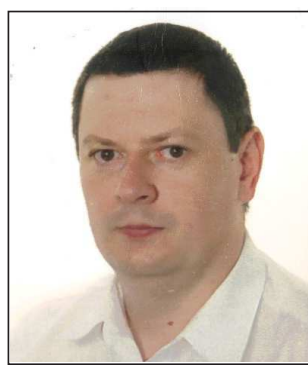

Tomasz Bryndal Geographer, researcher and academic teacher in the Department of Physical Geography at Pedagogical University in Cracow. Research interests related to: determination of natural and anthropogenic conditions of flash flooding, hydrological modeling of flash flood waves in small catchments

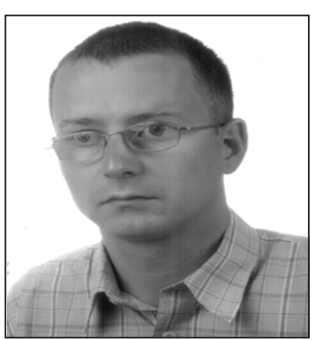

Rafal Kroczak Geographer, researcher and academic teacher in the Department of Physical Geography at Pedagogical University in Cracow. Research interests related to: hydrological aspects of road network functioning in mountains' environment, geomorphological aspects of road network development, hydrological modelling of flash floods in small catchments affected by human impact.

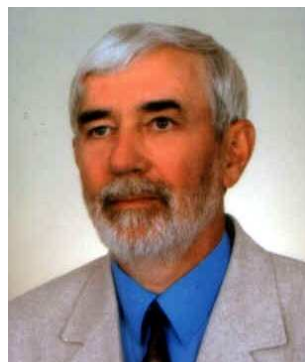

Roman Soja Geographer, professor in the Department of Physical Geography at Pedagogical University in Cracow. Research interests related to: the role of man and extreme events in the transformation of environment at the margin of the Eastern Himalaya and their piedmont, structure and a multi-year course of the precipitation in the Charrapunji Province. 